\title{
Profile of HMGB1 mRNA Expression and TLR4 Protein in BALB/c Mice Model Sterile Injury after Systemic Lidocaine Administration
}

\author{
Robert Hotman Sirait ${ }^{1}$, Mochammad Hatta ${ }^{2}$, Syafri K.Arief ${ }^{3}$, Tigor P. Simanjuntak ${ }^{4}$, Bambang Suprayogi ${ }^{5}$
}

\section{Robert Hotman Sirait ${ }^{1}$, Mochammad Hatta², Syafri K.Arief ${ }^{3}$, Tigor P. Simanjuntak ${ }^{4}$ Bambang Suprayogi ${ }^{5}$}

'Department of Anesthesiology, Faculty of Medicine, Christian University of Indonesia, Jakarta, Indonesia ${ }^{2}$ Molecular Biology and Immunology Laboratory, Faculty of Medicine, University of Hasanuddin, Makassar, Indonesia

${ }^{3}$ Department of Anesthesiology, Faculty of Medicine, University of Hasanuddin

Makassar, Indonesia

${ }^{4}$ Department of Obstetric and Gynecology, Faculty of Medicine, Christian University of Indonesia, Jakarta, Indonesia

${ }^{5}$ Department of Otorhinolaryngology, Faculty of Medicine, Christian University of Indonesia, Jakarta, Indonesia

\section{Correspondence}

Prof. Mochammad Hatta, M.D, Ph.D.

Molecular Biology and Immunology Laboratory, University of Hasanuddin Faculty of Medicine, Makassar, Indonesia Phone and Fax: 62-411-586971 / 62-411587464

E-mail: hattaram@yahoo.com

History

- Submission Date: 23-12-2017

- Review completed: 10-02-2018

- Accepted Date: 14-02-2018

DOI : 10.5530/pj.2018.3.96

Article Available online http://www.phcogj.com/v10/i3

\section{Copyright}

(C) 2018 Phcog.Net. This is an openaccess article distributed under the terms of the Creative Commons Attribution 4.0 International license.

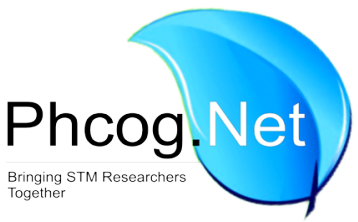

\begin{abstract}
Background: High mobility group box 1 (HMGB1) is a cytokine proinflamation which contributes to inflammation. HMGB1 physically interacts with toll like receptor 4 (TLR4) to release macrophage cytokines. The aim of this study was to demonstrate the effectiveness of systemic lidocaine administration to inhibit the expression of HMGB1 mRNA and TLR4 protein in mice BALB/C mice with sterile injury. Material and Methods: Twenty adult male BALB/c mice were divided into lidocaine and control groups. A sterile injury is done by closed fracturing the left thigh bone of the mice. The lidocaine group was treated with $2 \mathrm{mg} / \mathrm{kgBW}$ lidocaine through tail vein injection after $4 \mathrm{~h}$ of sterile injury. The control group was given distilled water therapy as a substitute for lidocaine. Mice blood is extracted from the tail vein before trauma, $4 \mathrm{~h}$ after trauma, and $2 \mathrm{~h}$ after the administration of lidocaine and distilled water is complete. The HMGB1 mRNA expression was examined by quantitative real-time polymerase chain reaction (qPCR) while the TLR4 protein level was determined with enzyme-linked immunosorbent assay (ELISA) according to the manufacturer's instructions. Result: The HMGB1 mRNA expression and TLR4 protein levels in BALB/C that sustained inflammation due to a sterile injury was significantly decreased in the lidocaine group $(p<0.00)$. Conclusion: Administration systemic $2 \mathrm{mg} / \mathrm{kgBW}$ of lidocaine is effectively inhibits HMGB1 mRNA and TLR4 protein in mice that sustain inflammation due to a sterile injury.

Keywords: HMGB1 mRNA, TLR4, lidocaine, sterile injury.
\end{abstract}

\section{INTRODUCTION}

HMGB1 is an DNA-binding nucleotide protein whose primary function is as a factor of transcriptional regulation and growth. ${ }^{1,2} \mathrm{HMGB} 1$ as a co-factor nuclear acting as an intracellular messenger molecule, is released to extracellular cells when injured or infected. ${ }^{3,4}$ Another role of HMGB1 is pro-inflammatory cytokines that contribute significantly in many cases of inflammation and sepsis. HMGB1 interacts with toll-like receptors (TLR4) to release macrophage cytokines. ${ }^{5,6}$ Lidocaine have analgesic and anti-arrhytmic effects, also have anti- inflammatory properties and cascade inflammation modulating effect on model sepsis mice induced with lipopolysaccharide. ${ }^{7,89}$ Previous studies have shown that administration of systemic lidocaine can inhibits HMGB1 mRNA expression and provides a protective effect against liver, lung and cardiac ischemia in model sepsis mice. ${ }^{10}$ The purpose of this study was to determine whether the administration of systemic lidocaine dose $2 \mathrm{mg} / \mathrm{kgBW}$ for $24 \mathrm{~h}$ can inhibit expression of HMGB1 mRNA and TLR4 protein level in $\mathrm{BALB} / \mathrm{c}$ mice who suffered sterile injury.

\section{MATERIAL AND METHODS}

This research is animal trial prospective laboratory study using healthy male BALB/c mice (weight 35-40 grams, age 10 -12 weeks; $\mathrm{n}=20$ ). Healthy BALB/c mice have glowing eyes, no dull feathers, active moves, and a good appetite. Mice that died during the study were excluded. Mice were obtained from the unit maintenance and development of animal trial Molecular Microbiology Laboratory and Immunology Faculty of Medicine, Hasanuddin University, Makassar, Indonesia. The mice were adapted and treated the following procedures and principles of the Declaration of Helskinki. BALB/c mice were divided into two groups: lidocaine group and control group, each group consist 10 mice. At first, blood from the tail vein each mouse was taken as much as $0.3 \mathrm{ml}$ to examine the expression of HMGB1 mRNA and TLR4 protein in first blood, mice then in anesthetized with ketamine $50 \mathrm{mg} / \mathrm{kgBW}$ intraperitoneally. Sterile injury is done by closed fracturing the left thigh bone of the mice using two needle holders. Four hours after the mice had a sterile injury, $0.3 \mathrm{ml}$ blood was taken again from tail vein for a second blood examination. The lidocaine group was given therapy with $2 \mathrm{mg} / \mathrm{kgBW}$ of lidocaine (2\% lidocaine, PT Kimia Farma, Jakarta, Indonesia) through tail vein injection, once every $2 \mathrm{~h}$, continuously until 24 $\mathrm{h}$. The control group was given distilled water as a replacement for lidocaine therapy. Two hours after

Cite this article: Sirait $\mathrm{RH}$, Hatta M, Arief SK, Simanjuntak TP, Suprayogi B. Profile of HMGB1 mRNA Expression and TLR4 Protein in BALB/c Mice Model Sterile Injury after Systemic Lidocaine Administration. Pharmacog J. 2018;10(3):586-9. 
the treatment of lidocaine and distilled water were completed, $0.3 \mathrm{ml}$ of blood was drawn again from the two study groups for a third blood test. All blood samples were mixed with L6 solution and processed into nucleic acid extract and stored at $-80^{\circ} \mathrm{C}$ before the qPCR and ELISA were examined.

\section{ELISA Assay}

The level of TLR4 protein in the serum and was determined with ELISA kits (Life Span Bioscience, Inc. of Seattle, North America) according to the manufacturer's instructions.

\section{Quantitative Real-time polymerase chain reaction (qPCR) Analysis}

The qPCR examination was performed using a PCR Bio-Rad BR004129USA machine. A mixture of $22.5 \mu \mathrm{l}$ PCR Mastermix and SYBR reen QRT was prepared. The following forward and reverse primers (1 $\mu \mathrm{l}$ each) for HMGB1, glyceraldehyde 3-phosphate dehydrogenase (GAPDH) as housekeeping gene, were used: (HMGB1 for, GAG ATC CTA AGA AGC CGA GA; HMGB1 Rev, CTT CCT CAT CCT CCT ATC; GAPDH for, GAC CAC AGT CCA TGC CAT CA; GAPDH Rev, CAT CAC BCC ACA CTT TCC). Next, $2.5 \mu$ of DNA extract was added to the $22.5 \mu \mathrm{l}$ mixture of primary PCR mix + primary. First stage amplification was performed at $94^{\circ} \mathrm{C}$ for $2 \mathrm{~s}$ and continued until 40 cycles $60 \mathrm{~s}$ at $94^{\circ} \mathrm{C}$, and $45 \mathrm{~s}$ at $57^{\circ} \mathrm{C}$. Then, the results come out in the form of data.

\section{Statistical analysis}

The data were processed using SPSS software version 20. The normally distributed data were compared with a Kolmogorov-Smirnov test and presented as mean $\pm \mathrm{SD}$. Comparison of data between groups were made using a t- test. A value of $\mathrm{p}<0.05$ was considered significant.

\section{Ethics statement}

The study was conducted after obtaining a recommendation letter of ethical clearance from the Medical Research Ethics Committee at the Faculty of Medicine, Hasanuddin University (Makassar, Indonesia) with registration number UH16050436 dated October 28, 2016.

\section{RESULTS}

The average weight of $\mathrm{BALB} / \mathrm{c}$ mice in the lidocaine group was 41.3 grams and in the control group of 39.34 grams. There was no significant difference between the two experimental groups $\mathrm{p}<0.05$.

i. Control group:

The initial HMGB1 mRNA expression mean \pm SD was $6.75 \pm 0.36$, after $4 \mathrm{~h}$ of sterile injury increased to $11.29 \pm 0.64$ and $2 \mathrm{~h}$ after distilled water administration increased steadily to $13.49 \pm 0.45$. The HMGB1 mRNA expression increase significantly, p value < 0.00 . Preliminary TLR4 protein content of mean \pm SD is $0.31 \pm$ 0.18 , after 4 hours of sterile injury increased to $1.67 \pm 0.26$ and $2 \mathrm{~h}$ after distilled water administration increased to $2.65 \pm 0.28$. TLR4 protein level increase significantly, p value $<0.00$.

The HMGB1 mRNA expression and TLR4 protein levels in both control groups can be seen in Figure 1.

ii. Lidocaine group:

The initial expression of the mean HMGB1 mRNA \pm SD was 6.73 \pm 0.66 , after $4 \mathrm{~h}$ of sterile injury increased to $11.90 \pm 0.62$ and 2 $\mathrm{h}$ after lidocaine therapy decreased to $6.94 \pm 0.51$. The mRNA HMGB1 expression decreases significantly, $\mathrm{p}$ value $<0.00$. Preliminary TLR 4 protein content of mean \pm SD is $0.30 \pm 0.13$, after $4 \mathrm{~h}$ of sterile injury increased to $1.83 \pm 0.24$ and $2 \mathrm{~h}$ after

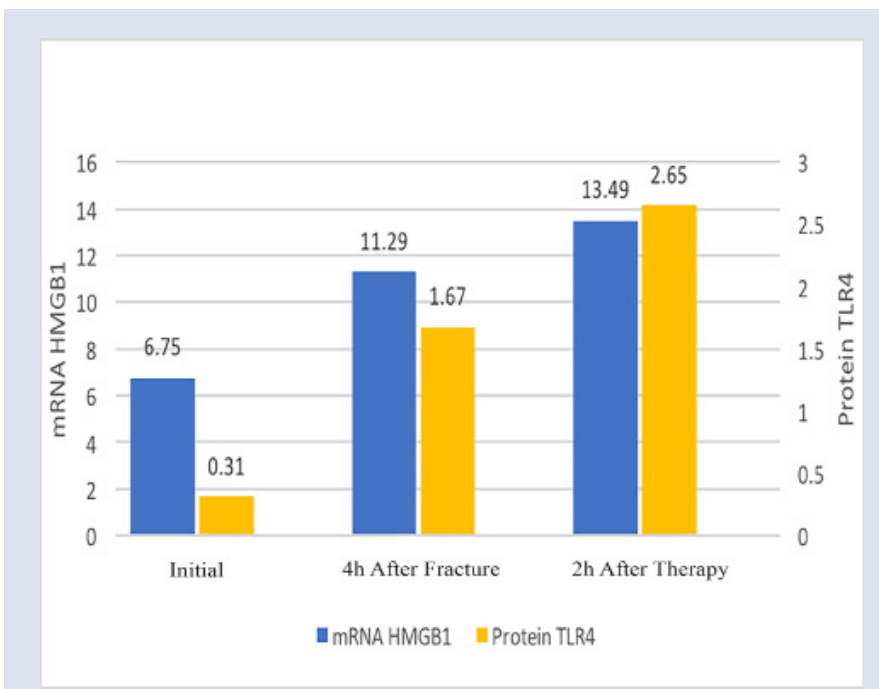

Figure 1: An expression of HMGB1 mRNA and TLR4 protein levels in both control groups

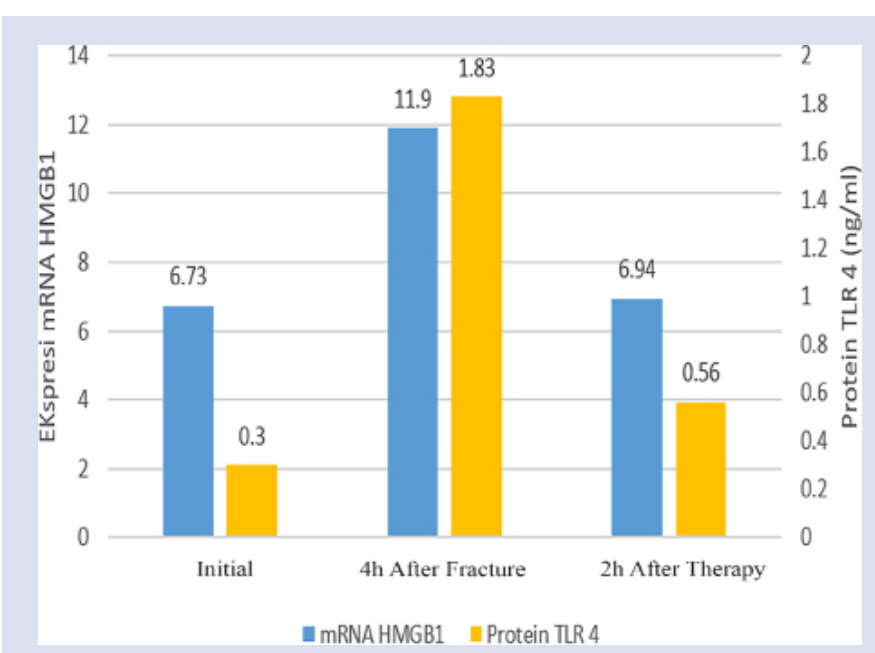

Figure 2: An expression of HMGB1 mRNA and TLR4 protein levels in both groups of lidocaine

lidocaine therapy decreased to $0.56 \pm 0.17$. Protein level TLR4 decreases significantly, $\mathrm{p}$ value $<0.00$.

The HMGB1 mRNA expression and TLR4 protein levels in both groups of lidocaine can be seen in Figure 2.

\section{DISCUSSION}

HMGB1 is a non-histone nuclear protein abundant and can be found in almost all types of mammalian cells. ${ }^{11} \mathrm{HMGB} 1$ includes a classic proinflammatory cytokine mediator, HMGB1 level will increase in blood in the event of injury or infection. ${ }^{12}$ HMGB1 is released passively from necrotic cells and actively from macrophage, monocyte, and dendritic cells. ${ }^{13}$ Excessive increased level of HMGB1 is always associated with worsening organ function. Extracellular HMGB1 will activate the signal path of TLR4 cell macrophages and dendrites. ${ }^{14,15}$ 
Our results show that HMGB1 mRNA expression and TLR4 protein levels can be found in normal $\mathrm{BALB} / \mathrm{c}$ mice blood. The expression of HMGB1 mRNA and TLR4 protein content increased after $4 \mathrm{~h}$ of BALB/c mice since sterile injury. Increase of mRNA HMGB1 expression and protein TLR4 shows that sterile injury within mice BALB/c results in severe inflammation. Control group express mRNA HMGB1 and TLR4 protein level statistically significant, $\mathrm{p}<0.00$. Result of this study shows that sterile aquadestila injection does not have therapeutical effect to inhibit inflammation.

The expression of mRNA HMGB1 in lidocaine group increased 1.8 times, from mean \pm SD: $6.73 \pm 0.66$ to $11.90 \pm 0.62$, and TLR4 protein level increased 6.2 times from mean \pm SD: $0.30 \pm 0.13$ to $1.83 \pm 0.24$. Increased expression of HMGB1 mRNA and TLR4 protein levels in the lidocaine group decreased after lidocaine therapy $2 \mathrm{mg} / \mathrm{kgBW}$ every $2 \mathrm{~h}$, continuously for $24 \mathrm{~h}$, each from mean \pm SD: $11.90 \pm 0.62$ to $6.94 \pm 0.51$ and from mean \pm SD: $1.83 \pm 0.24$ to $0.56 \pm 0.17$. decreased expression of mRNA HMGB1 and protein TLR4 is significant in statistic, p value $<0.00$. Our results show that $2 \mathrm{mg} / \mathrm{kgBW}$ lidocaine administration inhibits transcription of HMGB1 mRNA expression and translation of TLR4 protein in sterile injury BALB/c mice with sterile injury. ${ }^{16,17}$ Previously, Hollmann MW et al have shown that amide groups local anesthesia inhibited release of inflammatory mediators leukotrin B4 and interleukin-1 from human neutrophils and monocytes. ${ }^{8}$

In a previous reasearch, Wang HL et al demonstrated that administration of systemic lidocaine inhibits release of HMGB1 septic mice which induced with lypopolysaccharide ${ }^{10}$ and transcription of mRNA HMGB1 in patients during histerectomy. ${ }^{18}$ In a separate study, Liu J et al have shows that systemic lidocaine therapy protects dysfunction of kidney and liver in septic mice model with inhibiting expression of TLR4, NF- $\kappa \beta$ and interleukin-6. ${ }^{19}$

While the expression of HMGB1 mRNA and TLR4 protein levels in the control group increased steadily when compared from before the injury, $4 \mathrm{~h}$ after injury, and $2 \mathrm{~h}$ after administration of distilled water, $\mathrm{p}<0.00$. The results of this study show that administration of distilled water does not provide a therapeutic efficacy to inhibit inflammatory process.

The results of this study are consistent with the results of previous studies showing that systemic lidocaine therapy has anti-inflammatory properties in a number of sepsis disease models in experimental animals.

Within our hypothesis that $2 \mathrm{mg} / \mathrm{kgBW}$ intravenously administered lidocaine every 2 hours, continuously for 24 hours of efficacy is used to inhibit transcription of HMGB1 mRNA expression and TLR4 protein translation in sterile inflammation.

\section{CONCLUSION}

Intravenous administration $2 \mathrm{mg} / \mathrm{kgBW}$ of lidocaine therapy every 2 hours, continuously for 24 hours is effectively used to inhibits HMGB1 mRNA expression and TLR4 protein in BALB/c mice that sustain inflammation due to a sterile injury. Our results re-emphasize the importance of understanding that systemic lidocaine therapy has effect on antiinflammatory in many conditioned diseases caused by sterile inflammation or infection.

\section{CONFLICTS OF INTEREST}

The authors declare no conflicts of interest.

\section{ABBREVIATION USED}

mRNA: messenger Ribonucleic acid, HMGB1: High mobility group box 1, TLR4: Toll like receptor 4, qPCR: quantitative Real-time polymerase chain reaction, NF- $\kappa \beta$ : nuclear factor $\kappa \beta$.

\section{REFERENCES}

1. Magna M, Pisetsky DS. The Role of HMGB1 in the Pathogenesis of inflammatory and Autoimmune Diseases. Mol Med. 2014; 20 (1): 138-146.

2. Harris HE, Andersson U, Pisetsky PS. HMGB1: a multifunctional alarmin driving autoimmune and inflammatory disease. Nat. Rev Rheumatol. 2012; 8: 195-02.

3. Yang H, Antonie DJ, Andersson U, et al. The many faces of HMGB1: molecular structure-functional activity in inflammation, apoptosis, and chemotaxis. J Leukoc Biol. 2013; 93: 865-73

4. Yanai H, Ban T, Wang Z, Choi MK, Kawamura T, Negshi H, Nakasato M, et al. HMGB1 proteins function as universal sentinels for nucleic- acid-mediated innate immune responses. Nature 2009; 462: 99-103

5. Abbas KA, Lichtman AH, Pillai S. Cellular and Moleculer IMMUNOLOGI. $9^{\text {th }}$ ed. Chapter 4. Philadelpia: Elsevier Saunders; 2017: 51-85

6. Andersson $U$, Tracey KJ. HMGB1 is a therapeutic target for sterile inflammation and infection. Annu Rev Immunol. 2011; 29: 139-62.

7. Gallos G, Jones DR, Nasr SH, Emala CW and Lee HT. Local anesthetics reduce mortality and protect against renal and hepatic dysfuntion in murine septic peritonitis. Anesthesiology 2004; 101: 902-911.

8. Hollmann MW, Durieux ME. Local anesthetics and the inflammatory response: a new therapeutic indication. Anesthesiology. 2000; 93:858-75.

9. Caracas HC, Maciel JV, Martins PM, de Souza MM, Maia LC. The use of lidocaine as an anti-inflammatory substance: a systematic review. J Dent. 2009; 37: 93-7.

10. Wang $H L$, Ying $Y Q, Y u Y X$, Rong $F$, Lei WF, Zhang $W H$. The protective effect of lidocaine on septic rats via the inhibition of high mobility group box 1 expression and NF-кB activation. Mediators Inflamm. 2013; 570: 370.

11. Hreggvidsdottir HS, Ostberg T, Wahamaa $H$, et al. The alarmin HMGB1 acts in synergy with endogenous and exogenous danger signal to promote inflammation. J Leukoc Biol. 2009; 86: 655-62.

12. Venereau $E$, et al. Mutually exclusive redox forms of HMGB1 promote cell recruitment or proinflammatory cytokine release. J Exp Med. 2012;209:1519-28.

13. Scaffidi P, Mistell T, Bianchi ME. Release of chromatin protein HMGB1 by necrotic cells triggers inflammation. Nature. 2002; 418: 191-5.

14. Ueda T, Yoshida M. HMGB1 proteins and transcriptional regulation. Biochim Biophys Acta. 2010; 1799: 114-8.

15. Kagan JC, Su T, Horng T, Chow A, Akira S, Medzhitov R. TRAM couples endocytosis of Toll-like receptor 4 to the induction of interferon-beta. Nat. Immunol. 2008; 9: 361-368.

16. Sirait RH, Hatta M, Ramli M, Simanjuntak TP, Suprayogi P, Islam AA, Arief SK. The Analysis of the Effective Systemic Lidocaine Dosage on the Expression of HMGB1 mRNA on Mice with Sterile Musculoskeletal Injury. Open Journal of Anesthesiology. 2017; 7: 35-41.

17. Toshchakov VY, Szmacinski H, Couture LA, Lakowicz JR, Vogel, S. N. Targeting TLR4 signaling by TLR4Toll/IL-1 receptor domain-derived decoy peptides: identification of the TLR4 Toll/IL-1 receptor domain dimerization interface. J. Immunol. 2011; 186:4819-4827.

18. Wang HL, Liu YY, Yan HD, Wang XS, Hyang R, lie WF. Intraoperative systemic Lidocaine inhibits the expression of HMGB1 in patients undergoing radical hysterectomy. Int J Clin Exp Med. 2014; 7(10): 3398-3403.

19. Liu J, Zhang H, Qi Z, Zheng X. Lidocaine protects against renal and hepatic dysfunction in septic rats via downregulation of Toll-like receptor 4. Molecular Medicine Reports. 2014; 9: 118-124. 
GRAPHICAL ABSTRACT

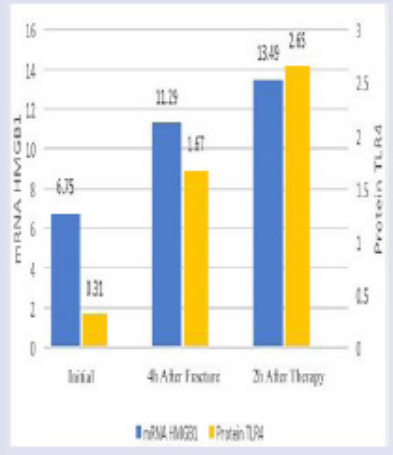

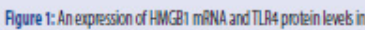
both control groups

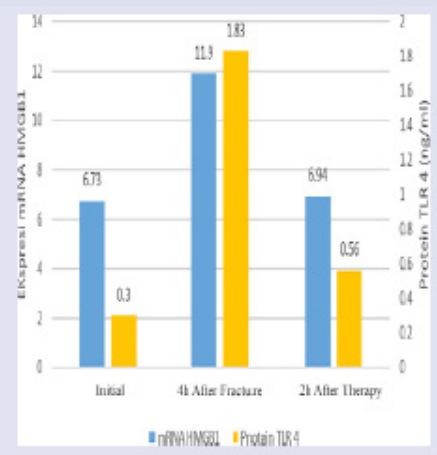

Figure 2: An expression of HMGB1 mRNA and TLR4 protein levels in both groups of lisocine

\section{SUMMARY}

High mobility group box 1 (HMGB1) is a cytokine proinflamation which contributes to inflammation. HMGB1 physically interacts with toll like receptor 4 (TLR4) to release macrophage cytokines. Administration systemic $2 \mathrm{mg} / \mathrm{kgBW}$ of lidocaine is effectively inhibits HMGB1 mRNA and TLR4 protein in mice that sustain inflammation due to a sterile injury.

\section{ABOUT AUTHORS}

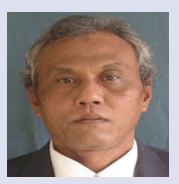

Prof. Mochammad Hatta, MD., Ph.D., Clin. Microbiologist (Cons) is a Professor on Molecular Biology and Immunology for Infectious Diseases from Medical Faculty of Hasanuddin University, Makassar, Indonesia.

Cite this article: Sirait RH, Hatta M, Arief SK, Simanjuntak TP, Suprayogi B. Profile of HMGB1 mRNA Expression and TLR4 Protein in BALB/c Mice Model Sterile Injury after Systemic Lidocaine Administration. Pharmacog J. 2018;10(3):586-9. 